\title{
EVALUATION OF OXIDATIVE STRESS, HYPOALBUMINEMIA AND ANEMIA IN CANCER
}

Lakshmana Kumar N¹, Mallikarjuna Rao K. V. N.2, Kishore K³, Kiran Deedi M4, Lakshmana Rao N5.

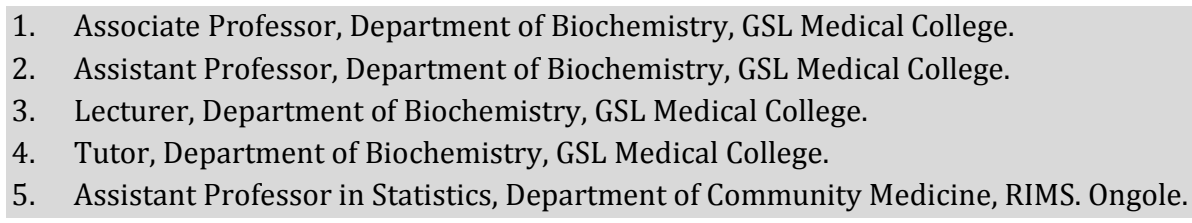

\section{CORRESPONDING AUTHOR:}

Dr. N. Lakshmana Kumar,

Associate Professor,

Department of Biochemistry,

GSL Medical College, NH-5, Lakshmipuram,

Rajahmundry, AP, India.

Email- luckylakshman@yahoo.com

ABSTRACT: - BACKGROUND: An attempt was made to study the role of Oxidative stress, Total protein, Albumin, A:G ratio \& Hemoglobin in cancer patients. MATERIALS AND METHODS: Malondialdehyde (MDA), Total proteins, Albumin: Globulin, Hemoglobin was measured in fifty (50) cases of cancer and fifty (50) controls RESULTS: There is significant increase in the MDA level in the case group compare to the control $(\mathrm{p}<0.0001)$. Total protein was more in the control group compare to the case but it was not significant ( $p>0.05$ ) Albumin level in cases was significantly less compared to control group ( $\mathrm{p}<0.05$ ), and there was a tendency towards the reversal of A-G ratio. Hemoglobin was significantly less in the case group compare to control $(p<0.05)$. CONCLUSION: Malondialdehyde (MDA) an end product of lipid peroxidation and oxidative stress was significantly increased in all cancer cases. Serum total proteins, especially albumin which act as reserve fuel in the body was decreased in cancer cases. The hemoglobin levels were also decreased in cancer cases.

INTRODUCTION: Reactive oxygen species [ROS] play an important role in the initiation and promotion of carcinogenesis (1). Oxidative stress and lipid peroxidation are involved in carcinogenesis (2). ROS and oxidative stress alter cellular signalling pathways and induces a cellular redox imbalance (3). Oxygen in molecular state is a poor oxidant since it contains two unpaired electrons. Oxygen can be reduced in four individual electron reactions to water. In this process it leads to the generation of three oxidants: super oxide ion, hydrogen peroxide, and the hydroxyl radical.

During the course of normal cellular processes free radicals are continuously generated and quenched. In health, the production and elimination of reactive oxygen species (ROS) is balanced. The conversion of molecular oxygen to ROS has been suggested to be involved in the genesis of ageing diseases (5). Lipid peroxides undergo cyclization to cyclic endoperoxides. Break down of these endoperoxides give rise to malondialdehyde (MDA) and thiobarbituric acid reactive substances (TBARS) $(6,7,8)$. Protein oxidation can lead to loss of critical sulfhydryl groups and modification of amino acids resulting in the formation of carbonyl and other oxidized molecules. 
When oxygen is partially reduced it becomes activated and reacts with variety of biomolecules. This partial reduction occurs in one electron steps by addition of one, two and four electrons to $\mathrm{O}_{2}$, leading to the formation of reactive oxygen metabolites (ROMs). The $\mathrm{O}_{2}$ and $\mathrm{H}_{2} \mathrm{O}_{2}$ formed in the presence of metal catalysts such as $\mathrm{Cu}^{+} / \mathrm{Fe}^{2+}$ may lead to formation of most reactive OH. $\mathrm{O}_{2}$ is reduced to $\mathrm{H}_{2} \mathrm{O}_{2}$ by the catalytic activity of Super oxide dismutase. Glutathione peroxidase and Catalase again convert $\mathrm{H}_{2} \mathrm{O}_{2}$ into $\mathrm{H}_{2} \mathrm{O}$. However accumulation of $\mathrm{O}_{2}$ and $\mathrm{H}_{2} \mathrm{O}_{2}$ results in the formation of $\mathrm{OH}$, which oxidizes lipids giving rise to lipid peroxidation $\mathrm{H}_{2} \mathrm{O}_{2}$ is known to cause DNA breaks in intact cells and purified DNA. Malondialdehyde (MDA) which is major end product cross links DNA and protein, and nucleotides on the same and opposite sides. MDA is mutagenic in mammalian systems which readily reacts with deoxy nucleosides to produce adducts. Products of lipid peroxidation may cause DNA damage. It may also play an indirect role in the conversion of procarcinogen to the ultimate carcinogens $(9,10,11)$. OH also interacts with DNA and causes many types of oxidized nucleosides 8-Hydroxy -2'- deoxy guanosine is one of the most commonly occurring products of these DNA modifications.

MATERIALS AND METHODS: In the present study 50 registered patients were selected from GSL Cancer hospital \& Research Centre, Rajahmundry. Study was approved by institutional ethics committee. Written and informed consent was obtained from all the participants. Venous blood samples of all the patients were collected in the heparin tubes for separation of plasma \& lysated for the biochemical assays. Venous blood samples were obtained from 50 age/gender matched controls with prior consent.

Data was analyzed by SPSS soft ware trial version 16.0.

Estimation of malondialdehyde- Thiobarbituric acid (TBA) reaction for MDA (12)

Estimation of total Proteins- Biuret method by using Autozyme reagent kit. $(13,14)$

Albumin - Bromocresol Green method by using Autozyme reagent kit. $(15,16)$

Estimation of Haemoglobin - Sahli's method by using Sahli's Hemoglobinometer. (17)

RESULTS: In the present study a total number of fifty cancer patients admitted in G.S.L. Trust Cancer Hospital and Research Centre, Rajahmundry were included. 50 people who were age and sex matched, apparently healthy subjects were also studied as controls. The age distribution of the patients in the present study, ranged from 25 to 76 years with a peak incidence at 51-60 years age group as shown in the table.

Statistical analysis was performed using the SPSS software. Care was taken to fulfill the essential characteristics of representative population e.g. sample size of $>30$ in each group (case $\mathrm{n}=50$ and Control $\mathrm{n}=50$ ) was investigated to avoid error due to chance.

Data are expressed as mean value \pm Standard Deviation (SD). Standard Deviation has been used to indicate whether the variation of difference of an individual from the mean is by chance. Statistical analysis was performed applying independent sample ' $t$ ' test to the data of independent samples for Equality of Means between the groups \& Levene's Test for Equality of Variances within the group. The probability value $(\mathrm{p})<0.05$ was considered statistically significant as this could be interpreted that the factor is less likely to occur due to chance, while a probability value $\quad(p)>0.05$ was considered statistically not significant because such a difference could commonly occur due to chance and the factor under study may have no influence on the variables. 
Table 4 \& 5 summarizes MDA status, Hb\% \& protein levels (Total, Albumin \& globulin) in the study group. After applying Independent sample $t$ test it was found that there was a significant increase in the MDA level in the case group compare to the control $(p<0.0001)$. Total protein was more in the control group compare to the case but it was not significant $(p>0.05)$ and there was a tendency towards the reversal of A-G ratio. $\mathrm{Hb} \%$ was significantly less in the case group compare to control $(\mathrm{p}<0.05)$.

DISCUSSION: The development of cancer follows a series of biochemical changes, and the susceptibility can be modulated by several factors. They were diet, hormonal status, radiation, genetic factors, environmental conditions etc. Little is known of the mechanisms of cancer induction, promotion and development processes. (18)

In recent years, free radicals have been implicated in the cancer process and some cancer causing factors have been thought to involve a series of stages which generate free radicals, particular those of molecular oxygen. (8)

Enzymatic and non-enzymatic defense mechanisms protect the cellular structures from damage by free radicals. Intra cellular distribution of these systems is important in the decomposition of toxic reactive intermediates because nucleic acids, proteins and also some enzymes, in the cell are found to be attacked by free radicals.

An increase of activated forms of molecular oxygen such as super oxide, Hydro peroxide, Hydrogen peroxide and singlet oxygen due to over production or inability to destroy them, may lead to severe damage in cellular structures. This leads to mutations, chromosomal aberrations and carcinogenesis. The active free radicals may also damage specific genes that control growth and differentiation during promotion phase and stimulate rapid growth and malignancy of cells. (19)

The elaborate defense system against oxygen in the cells consists of antioxidant enzymes and low molecular weight substances. These enzymes help to keep the steady state concentration of active oxygen at acceptable level under physiological conditions, and their inhibition can induce a pro oxidant state. Evidence for a role of pro oxidant states in carcinogenesis derives from the observation that super oxide, dioxygen and certain organic hydro peroxides are tumor promoters. $(20,21)$

Highly reactive oxygen species and free radical induced damage are implicated in carcinogenic processes. The production of active oxygen species by the circulating inflammatory cells, in tumor tissue may initiate the process of lipid peroxidation, which gives rise to active oxygen species.

Lipid peroxidation and product malondialdehyde (MDA) itself, due to its high cytotoxicity and inhibitory action on protective enzymes, is suggested to act as tumor promoter and carcinogenic agent. (22)

In our study of 50 cancer patients ( 19 males \& 31 females) of different organs were studied to establish the influence of lipid peroxidation and to figure out the oxidation and antioxidation in cancer. Majority of patients were habituated to mixed diet. Age is the powerful predictor of all cancer cases, mainly the peak incidence in the fifth decade. It is well known that tobacco use predisposes to the oropharyngeal cancer. In our study nine cases of oropharyngeal cancer were habituated to smoking the same finding is observed in the study of Arzu seven et al. (23) 
The results of our study show that lipid peroxidation as expressed by serum malondialdehyde (MDA) is significantly higher in oropharyngeal cancer patients in comparison to the control group $(\mathrm{p}<0.0001)$ as shown in table $2.0 z$ et al also observed significantly higher plasma MDA levels in oropharyngeal cancer. (24)

Lipid peroxidation has been implicated in the pathogenesis of various diseases and cancers. Bhavaraha Murty et al, (25) reported elevated lipid peroxides in uterine cervical cancer. In the present study also the levels of MDA are elevated significantly $(\mathrm{p}<0.0001)$. The similar results were observed in studies done by Basu J et al. (26). MDA levels were elevated in the breast cancer patients. The same finding was reported by Wang et al. (27) they demonstrated that MDA can accumulate in human breast tissue and reach high levels in the women with breast cancer. Oxidative stress may be associated with malignant disease (28)

Cancer Cachexia comprises several conditions including anorexia, asthenia, loss of lean body tissues and inability to alter some metabolic regulatory functions appropriate to the level of stress and nutritional status. Protein serves as a critical reserve of metabolic fuel. This becomes depleted during progressive malnutrition seen in cancer patients.

In the present study serum total proteins were more in the control group compared to the cancer cases but it was not statistically significant $(\mathrm{p}>0.05)$. There are mixed variations in protein fractions in different cancers.29 Albumin is more in control group compared to cases $(\mathrm{p}<0.005)$. As albumin is a nutritional reserve its levels are decreased in cancer cases. Exogenous albumin supplementation is required to correct hypoalbuminemia. 30 There is a tendency towards reversal of albumin: globulin ratio. Hemoglobin levels were significantly lower compared to controls $(\mathrm{p}<0.005)$. More than $30 \%$ of cancer patients suffer from anemia, which is a result of imbalance in cytokines like tumor necrosis factor, transforming growth factor, interleukins and interferons.31

CONCLUSION: In fifty (50) cases of cancer, Malondialdehyde (MDA), Total proteins, Albumin; Globulin were studied in serum. Hemoglobin level was also studied. Malondialdehyde (MDA) - an end product of lipid peroxidation was significantly increased in all cancer cases. Serum total proteins and Albumin- which act as reserve fuel in the body were decreased in cancer cases. The hemoglobin levels were also decreased in cancer cases.

ACKNOWLEDGEMENT: Authors expressed their sincere gratitude to all the participants for their cooperation.

CONFLICT OF INTEREST: There are no conflicts of interest in the present study. Funding: Authors have not received any funding for the present study.

\section{REFERENCES:}

1. Chen X, Ding YW, Yang G, Bondoc F, Lee MJ and Yang CS. Oxidative damage in an oesophageal adenocarcinoma model with rats. Carcinogenesis 2000; 21(2);257-263.

2. Sanchez-Perez Y, Carrasco-Legleu C, Garcia-Cuellar C, Perez-Carreon J, Hernandez-Garcia S, Salcido-Neyoy $\mathrm{M}$ et al: Oxidative stress in cancerogenesis. Correlation between lipid peroxidation and induction of preneoplastic lesions in rat hepatocarcinogenesis. Cancer Lett $2005 ; 217: 25-32$. 
3. Valko M, Rhodes CJ, Moncol J, Izakovic M and Mazur M: Free radicals, metals and antioxidants in oxidative stress-induced cancer. Chem Biol Interact 2006; 160(1): 1-40.

4. Fridovich I. The biology of oxygen radicals, Science 1978; 201: 875:80.

5. Ed D. Armstrong. Free radicals in Molecular Biology, ageing and disease. Raven Press1984:13-41.

6. Brown A.J., Dean R.T., Jessup W. Free and esterified oxysterol Formation during oxidation of low density lipoprotein and uptake by Macrophages. J Lipid Res 1994; 37:320-35.

7. Pryor W.A. Stanley J.P., Blair E. Auto oxidation of PUFA-II a suggested Mech. for the formation of TBA like material from prostaglandin like endoperoxides. Lipids 1976; 11: 370-79.

8. Ames BN. Dietary carcinogens and anti-carcinogens. Oxygen radicals and degenerative diseases Science 1983; 221: 1256-1264.

9. Flohe L, Beckmann R, Gietz H, Loschen G. Oxygen centered free radicals a mediators of inflammation, in oxidative stress, edited by H. Sies (Academic press. New York)1985; 405.

10. O'Brien’ P.J Antioxidants and cancer, Molecular mechanism in free radicals in diagnostic medicine, edited by D-Armstrong (Plenum press, New York) 1994; 215.

11. Smmer field FW, Tappel AL., Determination of fluorescence quenching of the environment of DNA cross links made of malanaldehyde. Biochemistry, Biophysics ACTA: 1983; 40:185.

12. MahfouzMD., Hariprasad.Ch. Shaffi, Sadasivudu. Serum Malonaldehyde levels in Myocardial Infarction and chronic renal failure, IRCS Med. Science 1986; 14:1110-11.

13. Strikland R.D., et al. Anal, Chem. 33, 1961.

14. Henri R.J., et al, "Clinical Chemistry - Principles and Techniques" Harper \& Row, 11 Ed. (1974).

15. Rodkey, F.L., Clin.Chem., 10 1964; 606.

16. Dumas. B.T., Watson.W.A., and Biggs. H.G., Clin.Chim.Acta., 31 (1971) 87.

17. Manual of Practical Physiology for M.B.B.S. - A.K.Jain.

18. Walch C.W. Host factors affecting growth of carcinogens induced rat mammary carcinomas. Cancer Res 1985; 45:3415-3443.

19. Freeman BA, Crapo JD Biology of disease, Free radicals and tissue, Lab Invest 1982;47: 412426.

20. Cerutte P.A. Pro oxidant status and Tumour promotion.Science1985; 227: 375-81.

21. Palan P. Goldberg GL., Basu J., Romney SL. Lipid soluble antioxidants carotene and tocopherol levels in breast and gynecological cancers. Gynaecol. oncol 1994;55 : 72-77.

22. Duthie G.G., Arthur J.R., James PT. Effects of smoking and vit E on blood oxidation status. American. J. Clin Nutr 1991; 53:1061-63.

23. Arzu Seven, S., Civelek, E., Inci F. Evaluation of oxidative stress parameter in blood of Patients with laryngeal carcinoma. Clinical Biochemistry 1999; 32: 369-73.

24. OZF., Gokkusu C and OZB. Lipid peroxidation and Glutathione levels in patients with pharyngeal Carcinoma. Med.Sci.Res1994; 22:193-4.

25. Bhavaramurty.V., BalaSubrahmanyam N. Effect of radio therapy on circulating antioxidant system of human uterine cervical carcinoma. Mol Cell Biochem 1996; 158: 17-23. 
26. Basu J, Mikhail MR. Antioxidant ascorbic acid and TBARS in plasma leucocytes and cervico vaginal cells in health and disease. American Journal of Obstetrics. And Gynecology 1990; 163:1948-52.

27. Wang MY, Dhingra K. et al Lipid peroxidation induced putative MDA-DNA adducts in breast tissues. Cancer Epidemiol Biomarkers Prev.1996; 5:705-10.

28. Hietanem E., Bartsch H.M., et al. Diet and oxidative stress in breast, colon and prostate cancer patients. Eur J Clin Nutr 1994;48:575-86.

29. Shoji Suga and Zyun Tamura. Analysis of Serum Protein Changes in Patients with Advanced Gastric Cancer with Special Reference to a-GIobulin Fractions1. Cancer Research 1972; 32:426-429.

30. Robert L. McCauley and Murray F. Brennan. Serum Albumin Levels in Cancer Patients Receiving Total Parenteral Nutrition. Ann Surg. 1983; 197(3):305-9.

31. Mario Dicato. Anemia in Cancer: Some Pathophysiological Aspects. The Oncologist 2003; $8(1): 19-21$.

TABLE 1: Age distribution in cancer patients

\begin{tabular}{|l|l|l|l|l|l|l|l|}
\hline Sl.No. & Age & \multicolumn{3}{|l|}{ Control } & \multirow{2}{*}{ Total } & \multicolumn{3}{|l|}{ Cancer } & Total \\
\cline { 3 - 4 } & Group & Male & Female & & Male & Female & \\
\hline 01. & $21-30$ & 2 & 3 & 5 & 1 & 1 & 2 \\
\hline 02. & $31-40$ & 2 & 3 & 5 & 2 & 4 & 6 \\
\hline 03. & $41-50$ & 4 & 6 & 10 & 5 & 6 & 11 \\
\hline 04. & $51-60$ & 6 & 9 & 15 & 2 & 11 & 13 \\
\hline 05. & $61-70$ & 4 & 6 & 10 & 5 & 7 & 12 \\
\hline 06. & $71-80$ & 2 & 3 & 5 & 4 & 2 & 6 \\
\hline Total & & 20 & 30 & 50 & 19 & 31 & 50 \\
\hline
\end{tabular}

Out of 50 cancer patients 19 were males (38\%) and 31 were females (62\%)

TABLE 2: Sex distribution in control and in cancer

\begin{tabular}{|l|l|l|l|l|}
\hline S.no & Sample & total & male & female \\
\hline 1. & Control & 50 & 20 & 30 \\
\hline 2. & Cancer & 50 & 19 & 31 \\
\hline
\end{tabular}

TABLE 3: Showing The Distribution Of Cancer Patients

\begin{tabular}{|l|l|l|l|l|}
\hline Sl.No. & Type of Cancer & Total & Male & Female \\
\hline 1 & Cervix & 14 & & 14 \\
\hline 2 & Oropharyngeal & 10 & 09 & 01 \\
\hline 3 & Breast & 05 & & 05 \\
\hline 4 & $\begin{array}{l}\text { Others(Lung \& Liver } \\
\text { Cancer etc.) }\end{array}$ & 21 & 10 & 11 \\
\hline \multicolumn{2}{|c|}{ Total } & 50 & 19 & 31 \\
\hline
\end{tabular}




\section{ORIGINAL ARTICLE}

TABLE 4: Group Statistics of the study population

\begin{tabular}{|l|l|l|l|l|l|l|}
\hline \multirow{2}{*}{ Group Status } & $\begin{array}{l}\text { MDA } \\
(\mathrm{n} \mathrm{mol} / \mathrm{dl})\end{array}$ & $\begin{array}{l}\text { T.P. } \\
(\mathrm{g} / \mathrm{dl})\end{array}$ & $\begin{array}{l}\text { ALB } \\
(\mathrm{g} / \mathrm{dl})\end{array}$ & $\begin{array}{l}\text { GLB } \\
(\mathrm{g} / \mathrm{dl})\end{array}$ & $\begin{array}{l}\text { Hb } \\
(\mathrm{g} \%)\end{array}$ \\
\hline $\begin{array}{l}\text { Case } \\
(\mathrm{n}=50)\end{array}$ & Mean & 664.40 & 7.25 & 3.89 & 3.36 & 10.82 \\
\cline { 2 - 7 } & S D & 129.19 & 0.51 & 0.53 & 0.46 & 2.65 \\
\hline $\begin{array}{l}\text { Control } \\
(\mathrm{n}=50)\end{array}$ & Mean & 259.00 & 7.82 & 5.23 & 2.63 & 13.74 \\
\cline { 2 - 7 } & S D & 59.013 & 0.53 & 0.25 & 0.37 & 3.23 \\
\hline
\end{tabular}

TABLE 5: Independent Samples't' Test for different variables of the study population (Control $n=50$, Case $n=50$ )

\begin{tabular}{|c|c|c|c|c|c|c|}
\hline \multirow[t]{2}{*}{ Variables } & & \multicolumn{2}{|c|}{$\begin{array}{l}\text { Levene's Test } \\
\text { for Equality of } \\
\text { Variances }\end{array}$} & \multicolumn{3}{|c|}{ t-test for Equality of Means } \\
\hline & & $\mathrm{F}$ & P Value & t & df & $\begin{array}{l}\text { P Value } \\
\text { (2-tailed) }\end{array}$ \\
\hline \multirow{2}{*}{$\begin{array}{l}\text { MDA } \\
(\mathrm{n} \mathrm{mol} / \mathrm{dl})\end{array}$} & $\begin{array}{l}\text { Equal variances } \\
\text { assumed }\end{array}$ & & \multirow[b]{2}{*}{0.0001} & -12.4 & 128 & 0.0001 \\
\hline & $\begin{array}{l}\text { Equal variances } \\
\text { not assumed }\end{array}$ & 25.52 & & -10.9 & 67.680 & 0.0001 \\
\hline \multirow{2}{*}{$\begin{array}{l}\text { T.P. } \\
(\mathrm{g} / \mathrm{dl})\end{array}$} & $\begin{array}{l}\text { Equal variances } \\
\text { assumed }\end{array}$ & & \multirow[b]{2}{*}{0.0001} & -24. & 128 & 0.056 \\
\hline & \begin{tabular}{|l} 
Equal variances \\
not assumed
\end{tabular} & 29.10 & & -20.8 & 61.960 & 0.06 \\
\hline \multirow{2}{*}{$\begin{array}{l}\text { ALB } \\
(g / d l)\end{array}$} & $\begin{array}{l}\text { Equal variances } \\
\text { assumed }\end{array}$ & & \multirow[b]{2}{*}{0.51} & 6.0 & 128 & 0.005 \\
\hline & \begin{tabular}{|l|} 
Equal variances \\
not assumed
\end{tabular} & 0.42 & & 6.13 & 108.646 & 0.045 \\
\hline \multirow{2}{*}{$\begin{array}{l}\text { GLB } \\
(g / d l)\end{array}$} & $\begin{array}{l}\text { Equal variances } \\
\text { assumed }\end{array}$ & & \multirow[b]{2}{*}{0.0001} & 19.3 & 128 & 0.005 \\
\hline & $\begin{array}{l}\text { Equal variances } \\
\text { not assumed }\end{array}$ & 33.83 & & 16.7 & 63.376 & 0.005 \\
\hline \multirow{2}{*}{$\begin{array}{l}\mathrm{Hb} \\
(\mathrm{g} \%)\end{array}$} & $\begin{array}{l}\text { Equal variances } \\
\text { assumed }\end{array}$ & & \multirow[b]{2}{*}{0.24} & -9.9 & 128 & 0.01 \\
\hline & $\begin{array}{l}\text { Equal variances } \\
\text { not assumed }\end{array}$ & 1.34 & & -9.4 & 88.644 & 0.005 \\
\hline
\end{tabular}

